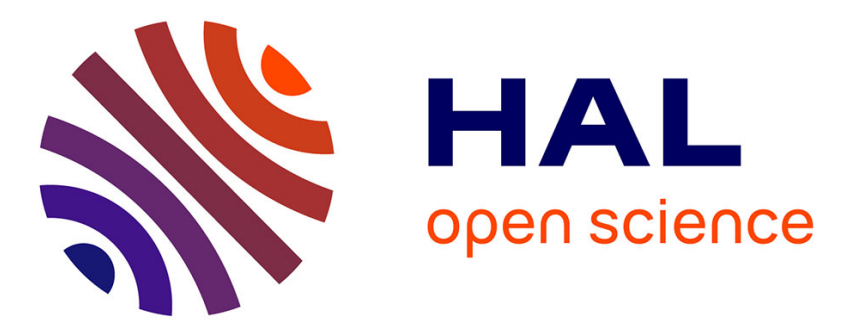

\title{
Reactivity of 5-aminopyrazoles bearing a cyclopropyl group at C3-position in palladium-catalyzed direct C4-arylation
}

\author{
Ameni Sidhom, Jean-François Soulé, Henri Doucet, Fatma Allouche
}

\section{To cite this version:}

Ameni Sidhom, Jean-François Soulé, Henri Doucet, Fatma Allouche. Reactivity of 5-aminopyrazoles bearing a cyclopropyl group at C3-position in palladium-catalyzed direct C4-arylation. Catalysis Communications, 2018, 115, pp.55-58. 10.1016/j.catcom.2018.07.008 . hal-01879771

\section{HAL Id: hal-01879771}

\section{https://hal-univ-rennes1.archives-ouvertes.fr/hal-01879771}

Submitted on 3 Oct 2018

HAL is a multi-disciplinary open access archive for the deposit and dissemination of scientific research documents, whether they are published or not. The documents may come from teaching and research institutions in France or abroad, or from public or private research centers.
L'archive ouverte pluridisciplinaire $\mathbf{H A L}$, est destinée au dépôt et à la diffusion de documents scientifiques de niveau recherche, publiés ou non, émanant des établissements d'enseignement et de recherche français ou étrangers, des laboratoires publics ou privés. 


\title{
Reactivity of 5-aminopyrazoles bearing a cyclopropyl group at
}

\section{C3-position in palladium-catalyzed direct C4-arylation}

\author{
Ameni Sidhom, ${ }^{\mathrm{a}, \mathrm{b}}$ Jean-Francois Soule ${ }^{\mathrm{b}}{ }^{*}$ Henri Doucet, ${ }^{\mathrm{b} *}$ Fatma Allouche ${ }^{\mathrm{a}}$ \\ ${ }^{a}$ Laboratoire de Chimie Médicinale et Environnementale, Institut Supérieur de Biotechnologie, Route de la Soukra km 4, 3038 Sfax, \\ Tunisie. \\ ${ }^{b}$ Univ Rennes, CNRS, ISCR-UMR 6226, F-35000 Rennes, France. E-mail: jean-francois-soule@univ-rennes1.fr, henri.doucet@univ- \\ rennes1.fr
}

\begin{abstract}
Pyrazole derivatives bearing a cy clopropyl group at C3-position and an amino substituent at C5 were successfully employ ed in palladium-catalyzed direct ary lations. These couplings were performed using air-stable $\operatorname{PdCl}\left(\mathrm{C}_{3} \mathrm{H}_{5}\right)(\mathrm{dppb})$ catalyst associated to KOAc as inexpensive base, and afforded regioselectively the C4-ary lated pyrazoles without decomposition of the cyclopropyl unit and formation of amination products. A wide variety of functional groups on the aryl bromide including electron-withdrawing and electron-donating ones such as nitrile, nitro, propionyl, ester, trifluoromethyl, chloro, fluoro or methoxy was tolerated. Moreover, from 5-aminopyrazoles bearing $\mathrm{N}$-2'-bromoaryl or 2'-bromobenzenesulfonamide substituent on the amino group, intramolecular Pd-catalyzed direct ary lations allowed the formation of tricy clic compounds by formation of 5- or 6-membered rings. () 2018 Elsevier Science. All rights reserved
\end{abstract}

Keywor ds: palladium, C-H bond functionalization, pyrazoles, cyclopropyl, aryl bromides

\section{Introduction}

Pyrazoles derivatives bearing a cyclopropyl unit are of considerable interest for pharmaceutical chemists due to their biological activities. Several molecules containing a cyclopropylpyrazole moiety such as compounds I-IV exhibit properties against some cancers; and some of them such as III and IV are under in vivo and in vitro investigation in the field of insulinlike growth factor and IGF-1 receptor which play an important role in cancer [1,2]. Therefore, the development of simple and reliable methods for the synthesis of 3-cyclopropylpyrazol derivatives, especially using commercially available 3cyclopropylpyrazoles is highly desirable. 

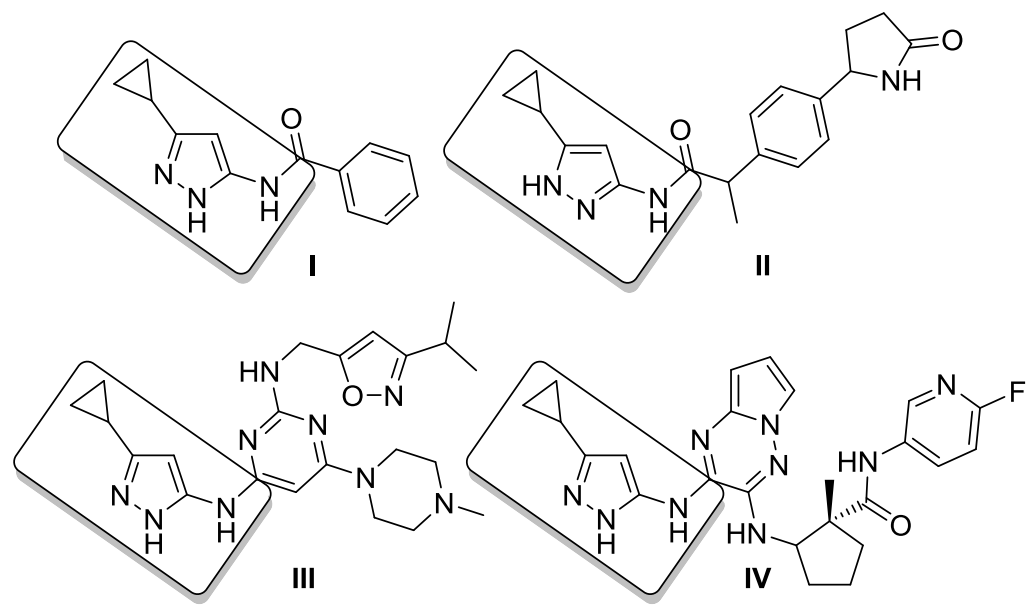

Figure 1. Examples of bioactive cyclopropyl-substituted aminopy razole derivatives.

The Pd-catalyzed direct arylation of a wide range of heteroaromatics [3-10], including pyrazoles [11-14], via a C-H bond activation of the heteroaromatics using aryl halides as aryl source has led to successes in recent years. Compared to classical palladium-catalyzed reactions such as Stille, Suzuki or Negishi couplings [15], such reactions are very attractive, as no preliminary preparation of organometallic derivatives is required. However, to our knowledge, no examples of palladium catalyzed direct arylations of pyrazoles bearing a cyclopropyl group has been described; whereas, several examples of preparation of C4-arylated 3-cyclopropylpyrazoles via Suzuki couplings have been reported in 2015 -2017 (Scheme 1, top) [16-20]. On the other hand, several examples of Pd-catalyzed direct functionalizations of the very reactive $\mathrm{sp}^{3} \mathrm{C}-\mathrm{H}$ bonds of cyclopropane units have been described [21-28]. Therefore, the tolerance to such cyclopropyl substituents on pyrazole in Pdcatalyzed direct arylations for a simple access to a variety of cyclopropyl-substituted pyrazole derivatives needed to be studied.

Herein, we report 1) on the influence of the nature of the base for the reaction of 3-cyclopropyl-1-methylpyrazol-5-amines with aryl bromides; 2) on the access to a wide variety of 4-arylated 3-cyclopropyl-1-methylpyrazol-5-amines using substituted aryl bromides; 3) on the formation of 5- and 6-membered rings through Pd-catalyzed intramolecular direct arylations of 5aminopyrazoles bearing 2-bromoaryl substituents on the amino group (Scheme 1, bottom). 
Previous work [16-20]

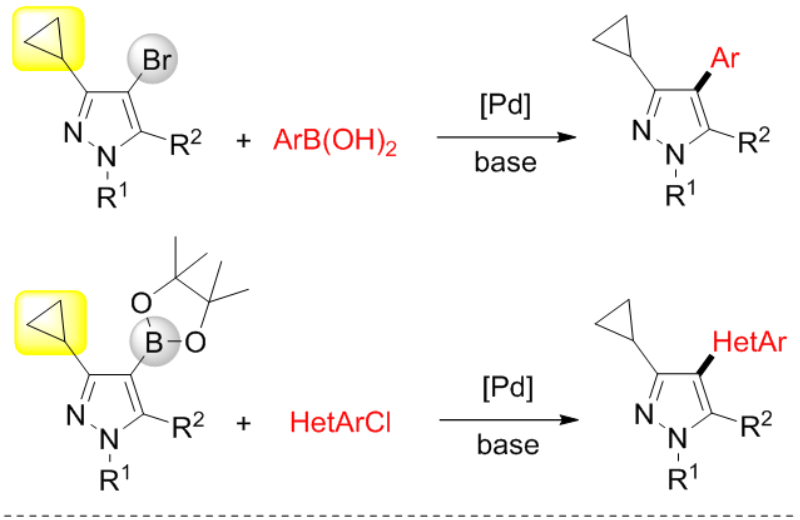

\section{This work}

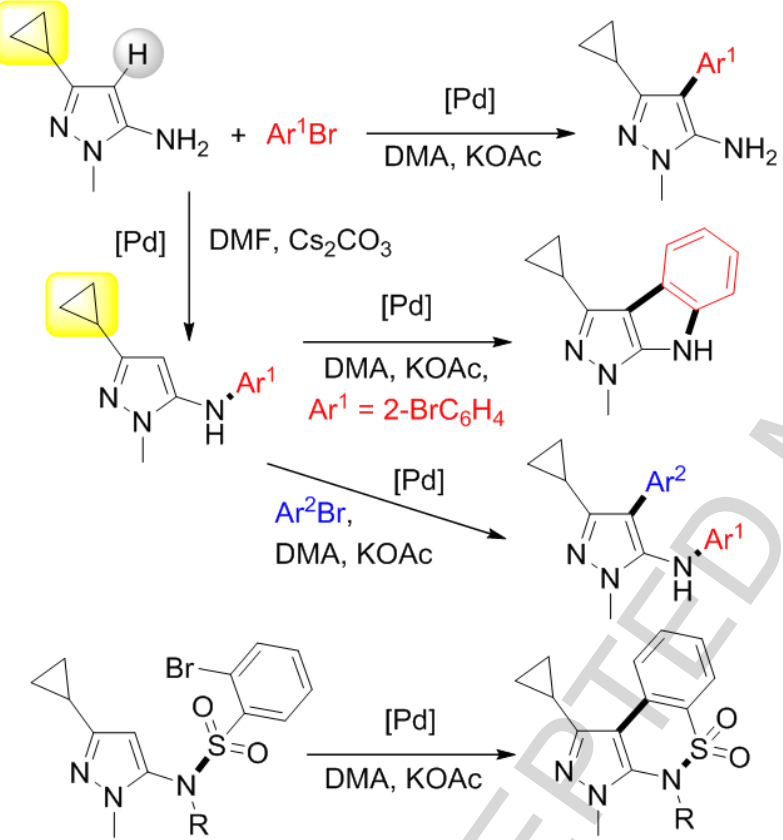

Scheme 1. Access to C4-ary lated 3-cy clopropyl-1-methylpy razole derivatives via Pd-catalyzed reactions.

\section{Results and discussion}

First, we examined the influence of the reaction conditions for the coupling of 3-cyclopropyl-1-methylpyrazol-5-amine with 4-bromobenzonitrile (Table 1). Starting form a slight excess of the aryl bromide (1.5 eq.) with respect to the pyrazole derivative, in the presence of $2 \mathrm{~mol} \% \mathrm{Pd}(\mathrm{OAc})_{2}$ as the catalyst, KOAc as the base, in DMA at $150^{\circ} \mathrm{C}$, the desired product $\mathbf{1 a}$ was obtained in only $51 \%$ yield (Table 1, entry 1). This moderate yield was due to a partial conversion of the pyrazole derivative; whereas no degradation of the cyclopropyl substituent was observed. It should be mentionned that, under these conditions, the amination product $\mathbf{1 b}$ was not detected. The use of 2 mol\% $\mathrm{PdCl}\left(\mathrm{C}_{3} \mathrm{H}_{5}\right)(\mathrm{dppb})$ catalyst [29] instead of 
$\mathrm{Pd}(\mathrm{OAc})_{2}$ under the same conditions produces 1a in 58-62\% yields with complete conversion of the pyrazole derivative

(Table 1, entry 2). The influence of a few bases on the selectivity and yield of the reaction was then examined, and both CsOAc and NaOAc led to mixtures of products $1 \mathbf{a}$ and $\mathbf{1 b}$ (Table 1, entries 3 and 4). On the other hand, no formation of $\mathbf{1 a}$ was observed in the presence of $\mathrm{Cs}_{2} \mathrm{CO}_{3}$ as base, and the amination product $\mathbf{1 b}$ was selectively obtained in $50 \%$ yield (Table 1, entry 6). The use of DMF as solvent with $\mathrm{Cs}_{2} \mathrm{CO}_{3}$ base allowed to slightly increase the yield in $\mathbf{1 b}$ to 53\% (Table 1 , entry 7). The difference in selectivity observed depending on the nature of the base can be explained by the concerted metalation deprotonation (CMD) mechanism involved in the direct arylation. The good performance of acetates as base/palladium ligand in (CMD) pathway has been demonstrated by Fagnou [30].

Table 1. Influence of the reaction conditions for palladium-catalyzed arylation of 3-cyclopropyl-1-methylpyrazol-5-amine with 4bromobenzonitrile.

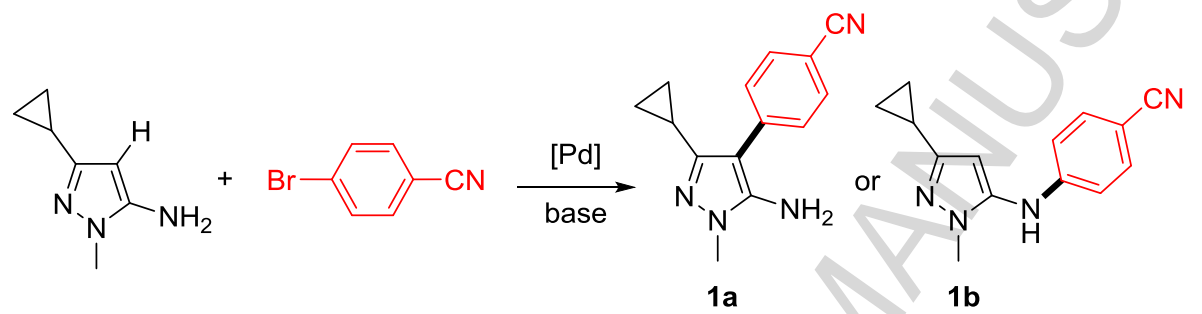

\begin{tabular}{|c|c|c|c|c|c|c|}
\hline Entry & Catalyst & Solvent & Base & Conv. $(\%)$ & Ratio 1a:1b & $\begin{array}{c}\text { Yield in 1a } \\
(\%)\end{array}$ \\
\hline 1 & $\mathrm{Pd}(\mathrm{OAc})_{2}$ & $\overline{\mathrm{DMA}}$ & KOAc & 67 & $100: 0$ & 51 \\
\hline 2 & $\operatorname{PdCl}\left(\mathrm{C}_{3} \mathrm{H}_{5}\right)(\mathrm{dppb})$ & & KOAc & 100 & 100:0 & $62,58^{\mathrm{b}}$ \\
\hline 3 & $\operatorname{PdCl}\left(\mathrm{C}_{3} \mathrm{H}_{5}\right)(\mathrm{dppb})$ & DMA & $\mathrm{CsOAc}$ & 100 & $84: 16$ & 50 \\
\hline 4 & $\operatorname{PdCl}\left(\mathrm{C}_{3} \mathrm{H}_{5}\right)(\mathrm{dppb})$ & DMA & $\mathrm{NaOAc}$ & 38 & $80: 20$ & nd \\
\hline 5 & $\operatorname{PdCl}\left(\mathrm{C}_{3} \mathrm{H}_{5}\right)(\mathrm{dppb})$ & DMA & $\mathrm{K}_{2} \mathrm{CO}_{3}$ & 100 & $10: 90$ & nd \\
\hline 6 & $\operatorname{PdCl}\left(\mathrm{C}_{3} \mathrm{H}_{5}\right)(\mathrm{dppb})$ & DMA & $\mathrm{Cs}_{2} \mathrm{CO}_{3}$ & 100 & $0: 100$ & $50^{\mathrm{a}}$ \\
\hline 7 & $\operatorname{PdCl}\left(\mathrm{C}_{3} \mathrm{H}_{5}\right)(\mathrm{dppb})$ & DMF & $\mathrm{Cs}_{2} \mathrm{CO}_{3}$ & 100 & $0: 100$ & $53^{\mathrm{a}}$ \\
\hline
\end{tabular}

Conditions: [Pd] $(0.02 \mathrm{mmol})$, 4-bromobenzonitrile (1.5 mmol), 3-cy clopropyl-1-methylpyrazol-5-amine (1 mmol), base (2 mmol), $150{ }^{\circ} \mathrm{C}$, $15 \mathrm{~h}$, argon, conversion of 3-cyclopropyl-1-methylpyrazol-5-amine. ${ }^{\text {a }}$ Yield in $\mathbf{1 b}$. ${ }^{\mathrm{b}} \mathrm{PdCl}\left(\mathrm{C}_{3} \mathrm{H}_{5}\right)(\mathrm{dppb})(0.1$ mmol), 4-bromobenzonitrile (7.5 mmol), 3-cy clopropyl-1-methy lpy razol-5-amine (5 mmol), KOAc (10 mmol).

Then, the scope of the C4-arylation of 3-cyclopropyl-1-methylpyrazol-5-amine using 2 mol\% $\mathrm{PdCl}\left(\mathrm{C}_{3} \mathrm{H}_{5}\right)(\mathrm{dppb})$ catalyst, $\mathrm{KOAc}$ as the base and DMA as the solvent at $150{ }^{\circ} \mathrm{C}$ was examined (Scheme 2). First, the reactivity of a set of para- 
substituted aryl bromides was studied. Good yields in the target products 2-6 were obtained from the electron-deficient aryl bromides bearing propionyl, ester, trifluoromethyl, chloro or fluoro substituents. Conversely, the use of 4bromonitrobenzene afforded 7 in low yield due to the formation of several degradation products. From the electron-rich bromobenzenes bearing tert-butyl- or methoxy-substituents at para-position, the coupling products 8 and 9 were isolated in $75 \%$ and $51 \%$ yields, respectively. Then, three meta-substituted aryl bromides have been employed, and again, the use of 2 mol\% $\mathrm{PdCl}\left(\mathrm{C}_{3} \mathrm{H}_{5}\right)(\mathrm{dppb})$ efficiently promoted the formation of 10-12 in 74-88\% yields from bromobenzenes bearing nitrile, chloro, or trifluoromethyl substituents. Then, we employed a range of ortho-substituted aryl bromides. Lower yields were obtained with 2-bromobenzonitrile, 2-bromochlorobenzene than with the para-substituted aryl bromides. From these two reactants, the desired products $\mathbf{1 3}$ and $\mathbf{1 4}$ were obtained in $64 \%$ and $61 \%$ yields, respectively. Heteroaryl bromide $3-$ bromoquinoline was also a suitable coupling partner, as the product $\mathbf{1 7}$ was obtained in $91 \%$ yield.

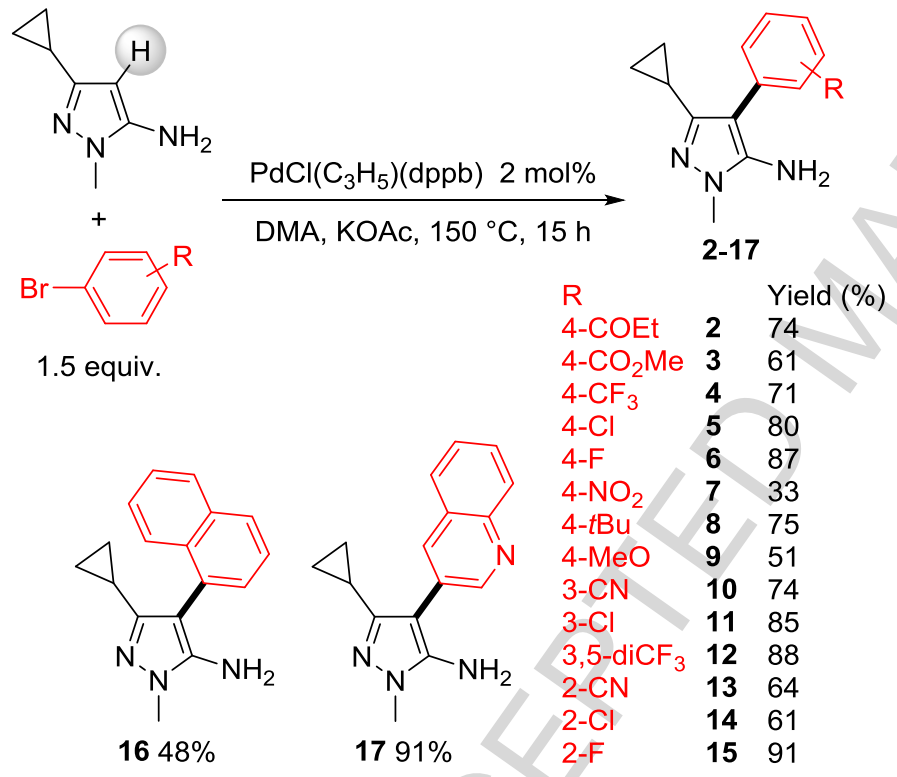

Scheme 2. Palladium-catalyzed direct C4-ary lation of 3-cy clopropyl-1-methylpy razol-5-amine with (hetero)aryl bromides.

As our amination procedure employs a quite cheap base and simple conditions, we also studied the scope of this reaction in order to prepare $N$-arylated 3-cyclopropylpyrazoles (Scheme 3). A set of substituted aryl bromides has been reacted with 3cyclopropyl-1-methylpyrazol-5-amine using $2 \mathrm{~mol} \% \mathrm{PdCl}\left(\mathrm{C}_{3} \mathrm{H}_{5}\right)(\mathrm{dppb})$ catalyst associated to $\mathrm{Cs}_{2} \mathrm{CO}_{3}$ as the base. These reaction conditions exclusively promoted the formation of the amination products $\mathbf{1 7 - 2 0}$ in $53-66 \%$ yields from bromobenzenes bearing nitrile, ester or even chloro substituents. Moreover, from 1,2-dibromobenzene, product 21 was obtained in $63 \%$ yield, without cleavage of the second $\mathrm{C}-\mathrm{Br}$ bond, allowing further transformations. 


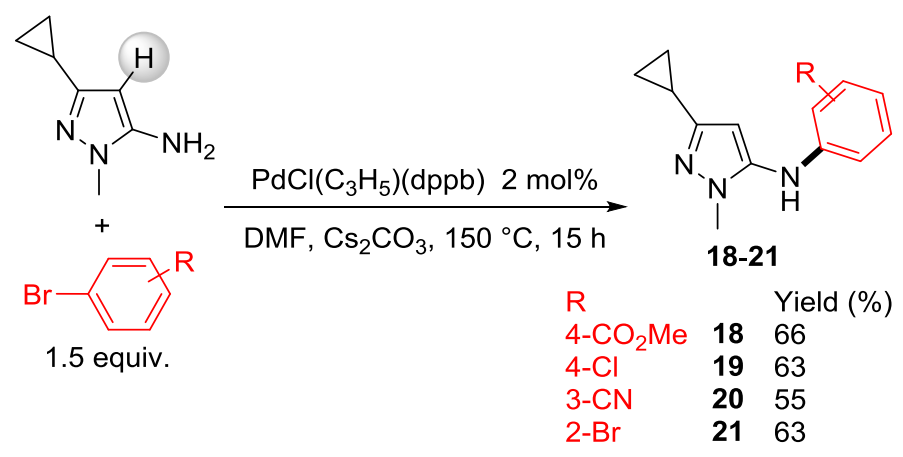

Scheme 3. Palladium-cataly zed amination of 3-cy clopropy l-1-methy lpyrazol-5-amine with aryl bromides.

Then, we examined the reactivity of the previously obtained $N$-arylated pyrazoles $\mathbf{1 b}$ and $\mathbf{2 1}$ (see table 1 , entry 7 and scheme 3) using direct arylation reaction conditions (Scheme 4). From 4-bromochlorobenzene and 1b, the C4-arylation product $\mathbf{2 2}$ was obtained in $76 \%$ yield (Scheme 4, top). Even the bromo-substituted $N$-arylpyrazole 21 was successfully arylated at C4position using 4-bromobenzonitrile as aryl source, affording product 23 in $71 \%$ yield, without cleavage of the $\mathrm{C}$-Br bond of the aryl on the pyrazolyl derivative (Scheme 4, bottom). No Pd-catalyzed intramolecular cyclization of 21 to give 24 (see scheme 5) was detected. This selectivity is due to the easier oxidative addition of 4-bromobenzonitrile compared to the 2bromoaniline unit to palladium.

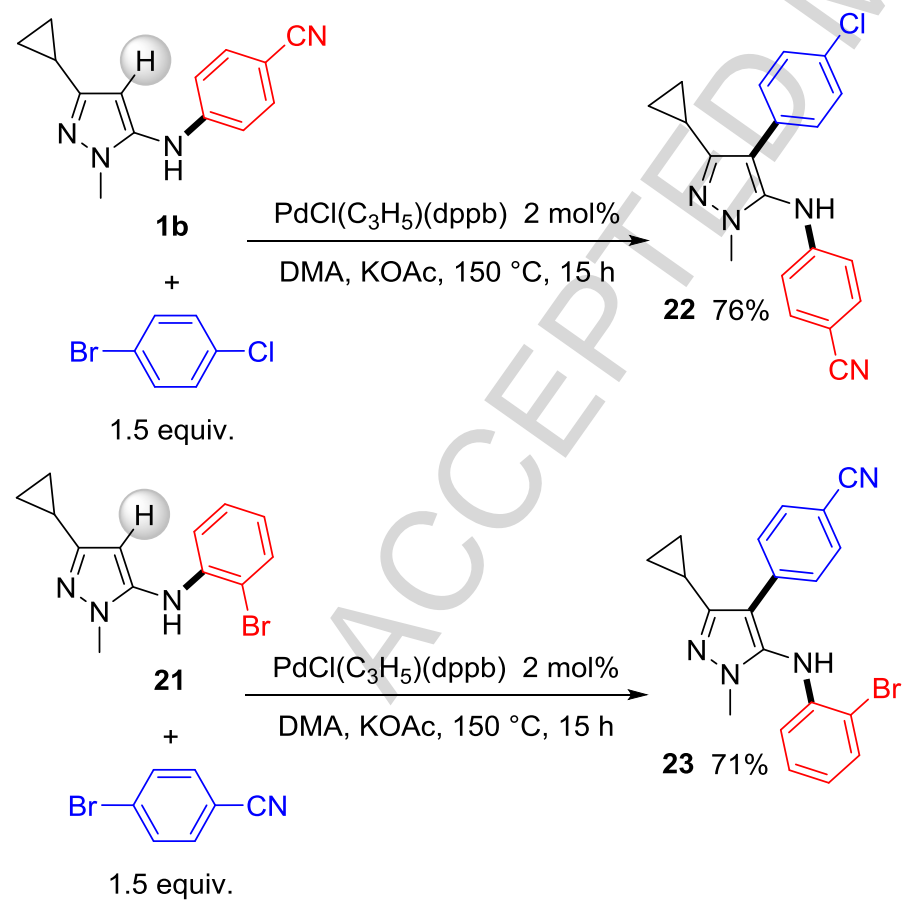

Scheme 4. Palladium-cataly zed direct C4-ary lation of 3-cy clopropyl-1-methy lpy razol-5-amine derivatives with aryl bromides.

The synthesis of 1,8-dihydropyrazolo[3,4-b]indoles bearing a cyclopropyl unit at C3-position has not been reported so far. Therefore, we investigated the reactivity of compound $\mathbf{2 1}$ in Pd-catalyzed intramolecular direct arylation (Scheme 5, top). 
The use of $2 \mathrm{~mol} \% \mathrm{PdCl}\left(\mathrm{C}_{3} \mathrm{H}_{5}\right)(\mathrm{dppb})$ catalyst in the presence of $\mathrm{KOAc}$ at $150{ }^{\circ} \mathrm{C}$ gave selectively the desired 3cyclopropylpyrazolo[3,4-b]indole derivative $\mathbf{2 4}$ in $88 \%$ yield. No intermolecular coupling was detected in the course of this reaction.

To our knowledge, the synthesis of 3,4-dihydrobenzo[ $e]$ pyrazolo[3,4-c][1,2]thiazines has never been described. In order to have access to a 3,4-dihydrobenzo[e]pyrazolo[3,4-c][1,2]thiazine, we prepared the 2-bromo- $N$-(pyrazol-5yl)benzenesulfonamide derivative 25 by reaction of 3-cyclopropyl-1-methylpyrazol-5-amine with 2-bromobenzenesulfonyl chloride (Scheme 5, bottom). Using product 25 and $2 \mathrm{~mol} \% \mathrm{PdCl}\left(\mathrm{C}_{3} \mathrm{H}_{5}\right)(\mathrm{dppb})$ catalyst associated to $\mathrm{KOAc}$ at $150{ }^{\circ} \mathrm{C}$, no trace of the desired cyclization product $\mathbf{2 7}$ was detected. Conversely, the sulfonamide $\mathbf{2 6}$ bearing both a pyrazolyl and a propyl group on the nitrogen atom, under the same reaction conditions, afforded the target tricyclic product $\mathbf{2 8}$ in very high yield.

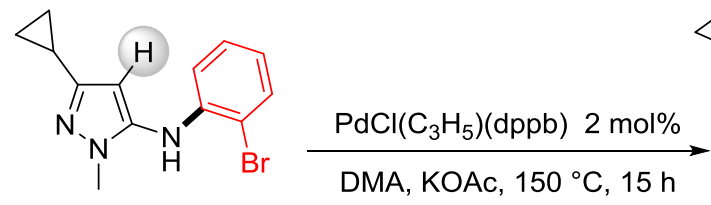

21

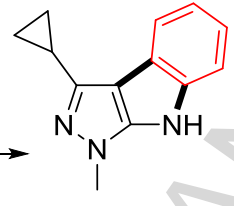

$2488 \%$
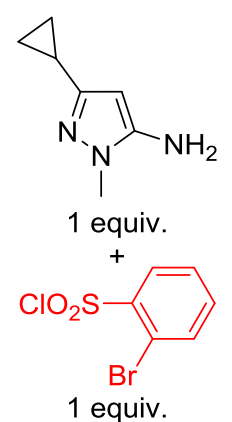

$\mathrm{NEt}_{3}, 25^{\circ} \mathrm{C}, 15 \mathrm{~h}$

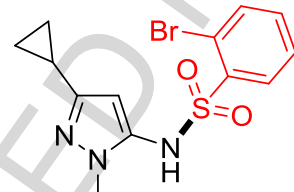

$2573 \%$

lodopropane (2 equiv.), $\mathrm{K}_{2} \mathrm{CO}_{3}$

(2 equiv.), DMF $90{ }^{\circ} \mathrm{C}, 15 \mathrm{~h}$
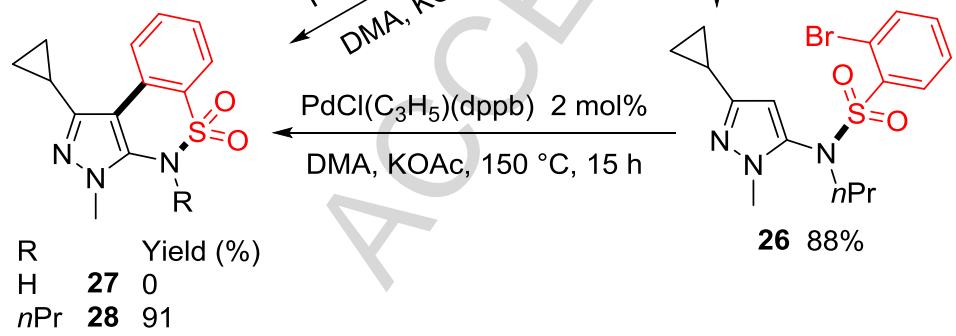

$2688 \%$

Scheme 5. Formation of 5- and 6-membered rings via palladium-catalyzed intramolecular direct arylations.

In summary, we have demonstrated that using $\mathrm{PdCl}\left(\mathrm{C}_{3} \mathrm{H}_{5}\right)(\mathrm{dppb})$ catalyst in the presence of KOAc base, the C4-arylation via $\mathrm{C}-\mathrm{H}$ bond activation of 3-cyclopropyl-1-methylpyrazol-5-amine proceeds in moderate to high yields. Conversely, the use of $\mathrm{Cs}_{2} \mathrm{CO}_{3}$ base afforded the amination product. No decomposition of the cyclopropyl group was observed for both procedures. 
The direct arylation procedure gave good results using both electron-rich and electron-deficient aryl bromides. Several useful functional groups such as propionyl, ester, nitro, nitrile, trifluoromethyl, chloro, fluoro or methoxy were tolerated on the aryl bromide, and even the heteroarene 3-bromoquinoline gave a satisfactory result. Moreover, from 5-aminopyrazoles bearing $N$-2'-bromoaryl or 2'-bromobenzenesulfonamide substituents on the amino group, intramolecular Pd-catalyzed direct arylations allowed the formation of 5- or 6-membered rings. This procedure is attractive from both synthetic and environmental points of view, as with this $\mathrm{C}-\mathrm{H}$ bond functionalization procedure, no preparation of an organometallic derivative is required, and as the major waste of this coupling reaction is the relatively non-toxic $\mathrm{AcOH} / \mathrm{KBr}$ instead of the mixture of metallic salts obtained with more classical metal-catalyzed coupling reactions. For these reasons, this methodology is very promising for the tuning of the biological properties of cyclopropyl-substituted pyrazoles.

\section{References}

[1] E. R. King, K.-K. Wong, Recent Pat. Anticancer Drug Discov. 7 (2012) 14-30.

[2] J. Cicenas, E. Cicenas, Med. Oncol. 33 (2016), 1-11.

[3] A. Ohta, Y. Akita, T. Ohkuwa, M. Chiba, R. Fukunaga, A. Miyafuji, T. Nakata, N. Tani, Y. Aoy agi, Heterocycles 31 (1990) 1951-1958.

[4] F. Bellina, R. Rossi, Tetrahedron 65 (2009) 10269-10310.

[5] L. Ackermann, R. Vincente, A. R. Kapdi, Angew. Chem. Int. Ed. 48 (2009) 9792-9826.

[6] J. Wencel-Delord, F. Glorius, Nature Chem. 5 (2013) 369-375.

[7] R. Rossi, F. Bellina, M. Lessi, C. Manzini, Adv. Synth. Catal. 356 (2014) 17-117.

[8] C. B. Bheeter, L. Chen, J.-F. Soulé, H. Doucet, Catal. Sci. Technol. 6 (2016) 2005-2049.

[9] R. Rossi, M. Lessi, C. Manzini, G. Marianetti, F. Bellina, Tetrahedron 72 (2016) 1795-1837.

[10] T. Gensch, M. J. James, T. Dalton, F. Glorius, Angew. Chem. Int. Ed. 57 (2018) 2296-2306.

[11] S. Kumar, H. Ila, H. Junjappa, J. Org. Chem. 74 (2009) 7046-7051.

[12] Y. Fall, H. Doucet, M. Santelli, Synthesis (2010) 127-135.

[13] T. Yan, L. Chen, C. Bruneau, P. H. Dixneuf, H. Doucet, J. Org. Chem. 77 (2012) 7659-7664.

[14] L. Tenora, J. Galeta, E. Reznickova, V. Krystof, M. Potacek, J. Org. Chem. 81 (2016) 11841-11856.

[15] L. Ackermann, Modern arylation methods, Eds.: Wiley Online Library, 2009.

[16] A. W. Brown, J. P. A. Harrity, Tetrahedron 73 (2017) 3160-3172. 
[17] T. Fukuda, R. Goto, T. Kiho, K. Ueda, S. Muramatsu, M. Hashimoto, A. Aki, K. Watanabe, N. Tanaka, Bioorg. Med. Chem. Lett. 27 (2017) 3716-3722.

[18] T. Fukuda, R. Goto, T. Kiho, K. Ueda, S. Muramatsu, M. Hashimoto, A. Aki, K. Watanabe, N. Tanaka, Bioorg. Med. Chem. Lett. 27 (2017) 5252-5257.

[19] Y. Zhao, L. Bai, L. Liu, D. McEachern, J. A. Stuckey, J. L. Meagher, C.-Y. Yang, X. Ran, B. Zhou, Y. Hu, X. Li, B. Wen, T. Zhao, S. Li, D. Sun, S. Wang, J. Med. Chem. 60 (2017) 3887-3901.

[20] X. Ran, Y. Zhao, L. Liu, L. Bai, C.-Y. Yang, B. Zhou, J. L. Meagher, K. Chinnaswamy, J. A. Stuckey, S. Wang, J. Med. Chem. 58 (2015) 4927-4939.

[21] S. Rousseaux, B. Liégault, K. Fagnou, Chem. Sci. 3 (2012) 244-248.

[22] M. Wasa, K. S. L. Chan, X.-G. Zhang, J. He, M. Miura, J.-Q. Yu, J. Am. Chem. Soc. 134 (2012) 18570-18572.

[23] R. Parella, B. Gopalakrishnan, S. A. Babu, Org. Lett. 15 (2013) 3238-3241.

[24] J. Pedroni, T. Saget, P. A. Donets, N. Cramer, Chem. Sci. 6 (2015), 5164-5171.

[25] J. Kim, M. Sim, N. Kim, S. Hong, Chem. Sci. 6 (2015) 3611-3616.

[26] K. S. L. Chan, H.-Y. Fu, J.-Q. Yu, J. Am. Chem. Soc. 137 (2015) 2042-2046.

[27] C. L. Ladd, A. V. Belouin, A. B. Charette, J. Org. Chem. 81 (2016) 256-264.

[28] B. Gopalakrishnan, S. Mohan, R. Parella, S. A. Babu, J. Org. Chem. 81 (2016) 8988-9005.

[29] T. Cantat, E. Génin, C. Giroud, G. Meyer, A. Jutand, J. Organomet. Chem. 687 (2003) 365-376.

[30] S. I. Gorelsky, D. Lapointe, K. Fagnou, J. Am. Chem. Soc. 130 (2008) 10848-10849. 
*Highlights (for review)

- Selective arylation of 3-cyclopropyl-1-methylpyrazol-5-amine at C4 position

- amination $v s$ arylation is controlled by the nature of base and solvent

- Intramolecular reactions allow the synthetises of polycyclic aromatics 


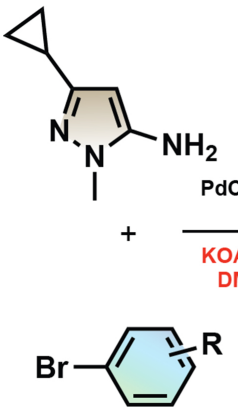

\section{Intramolecular C-H Bond Ayylation}

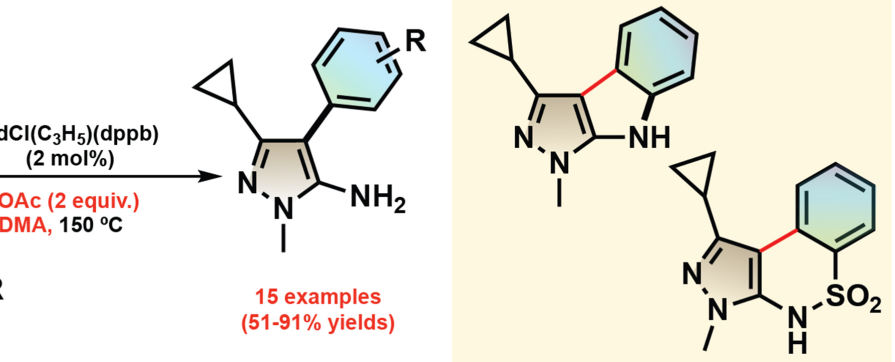



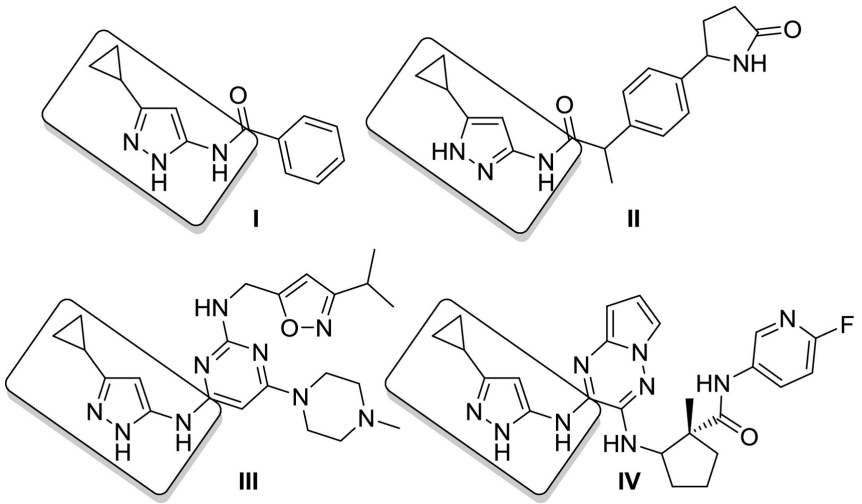

Figure 1 